\title{
Storage Performance of Hot Water Treated Kinnow Fruits under Ambient Conditions
}

\author{
Rachna Singla, H.S. Rattanpal* and Gurteg Singh \\ Department of Fruit Science, Punjab Agricultural University, \\ Ludhiana - 141 004, Punjab, India \\ *Corresponding author
}

\section{A B S T R A C T}

\section{Keywords}

Sodium

bicarbonate, Ambient, Post harvest, Shelf life

Article Info

Accepted:

25 May 2018

Available Online:

10 June 2018
This study was conducted to access the effect of hot water and sodium bicarbonate treatments on the storage performance of Kinnow under ambient conditions. The fruits were subjected to hot water treatments at different temperatures $\left(45,50\right.$ and $\left.55^{\circ} \mathrm{C}\right)$, sodium bicarbonate at different levels ( $2 \%$ or $3 \%)$ and their combinations. The control fruits were kept untreated. All the fruits were stored at room temperature for 0-21days. The results show that fruit weight loss, total soluble solids and disease incidence increased significantly with the storage time, however, the acid contents declined thereafter. Hot water $50^{\circ} \mathrm{C}$ alone and in combination with sodium bicarbonate $(2 \%)$ retarded the changes associated with the storage duration in Kinnow mandarin. It was also observed that exposure to high temperature (above $50^{\circ} \mathrm{C}$ ) reversed the beneficial effects and enhanced the decline in physical and chemical quality attributes of Kinnow fruits.

\section{Introduction}

Vitamins are an extremely diverse range of organic compounds present in minute amounts in natural foodstuffs. They are vital in the enzyme reactions that are necessary for carbohydrate, fat, and protein metabolism. Vitamins are classified into two groups: watersoluble and fat-soluble. Vitamins are relatively unstable, affected by factors such as heat, light, air, other food components and even food processing conditions. Vitamin play a critical role in nutrition. Food manufacturers face a challenging task due to their relative instability and it is important to have their qualitative and quantitative analysis for nutrition and food industry.

\section{Materials and Methods}

Fruit were randomly divided into twelve treatment groups, each of 75 fruits. The first group was used as the control, without any treatment, second group was dipped in sodium bicarbonate solution having a final concentration of $2 \%(\mathrm{w} / \mathrm{v})$ for 2 minutes, third group was dipped in sodium bicarbonate solution having a final concentration of $3 \%$ (w/v) for 2 minutes, fourth group was dipped in hot water at $45^{\circ} \mathrm{C}$ for 2 minutes, fifth group 
was dipped in hot water at $50^{\circ} \mathrm{C}$ for $2 \mathrm{~min}$ sixth group was dipped in hot water at $55^{\circ} \mathrm{C}$ for 2 minutes, other six groups were treated with combination of hot water (HW) at three temperatures $\left[45,50\right.$, and $\left.55^{\circ} \mathrm{C}\right]$ and sodium bicarbonate ( 2 and $3 \% \mathrm{w} / \mathrm{v}$ ) for 2 minute each. All these treatments were followed by a gentle breeze from a fan to remove the surface water. These were then packed in cardboard boxes (530 x $200 \times 200 \mathrm{~mm})$ having 5\% holes on each side for ventilation. The fruit were then stored at room temperature and data was recorded on physico-chemical quality attributes of fruits at 7 days interval for 21 days. Biochemical quality attributes such as total soluble solids (TSS), acidity, TSS: acid ratio, reducing and non-reducing sugars and ascorbic acid content were determined according to AOAC, (1990). The data calculated on different parameters were subjected to Analysis of Variance (ANOVA) technique by using completely randomized design (Panse and Sukhatame, 1976) to observe the difference between the different treatments as well as their interactions.

\section{Results and Discussion}

\section{Physiological loss in weight (PLW)}

The physiological loss in weight was significantly affected by heat treatment and storage duration (Table 1). The data indicate that the mean minimum loss in weight (4.28 and $4.26 \%$ in $1^{\text {st }}$ year and $2^{\text {nd }}$ year, respectively) was observed in fruits treated with hot water $\left(50^{\circ} \mathrm{C}\right)$ dipping. The mean maximum PLW was recorded in control (4.78 and $4.73 \%$ in $1^{\text {st }}$ year and $2^{\text {nd }}$ year, respectively) followed by hot water $\left(55^{\circ} \mathrm{C}\right)+$ sodium bicarbonate $(3 \%)$, hot water $45^{\circ} \mathrm{C}+$ sodium bicarbonate $(3 \%)$, hot water $\left(55^{\circ} \mathrm{C}\right)+$ sodium bicarbonate (2\%). There was a continuous increase in mean weight loss with increase in storage duration. The weight loss was increased significantly from the minimum
(2.35 and $2.32 \%$ in $1^{\text {st }}$ year and $2^{\text {nd }}$ year, respectively) after 7 days of storage to 4.42 and 4.38 per cent in $1^{\text {st }}$ year and $2^{\text {nd }}$ year respectively after 14 days storage and maximum weight loss (6.83 and $6.78 \%$ in $1^{\text {st }}$ year and $2^{\text {nd }}$ year, respectively) was observed after 21 days of storage.

\section{Rotting percentage}

The mean minimum rotting percentage (1.33 and $0.89 \%$ in $1^{\text {st }}$ year and $2^{\text {nd }}$ year, respectively) was observed in fruit treated with sodium bicarbonate $(2 \%)$ followed by sodium bicarbonate $(3 \%)(2.22 \%$ during both the seasons) in ascending order and both these treatments differed significantly from each other (Table 2). The maximum rotting percentage was recorded in fruits treated with hot water $\left(55^{\circ} \mathrm{C}\right)\left(8.89\right.$ and $9.78 \%$ in $1^{\text {st }}$ year and $2^{\text {nd }}$ year, respectively) followed by hot water $\left(55^{\circ} \mathrm{C}\right)+$ sodium bicarbonate $(3 \%)$, hot water $\left(55^{\circ} \mathrm{C}\right)+$ sodium bicarbonate $(2 \%)$. The rotting percentage increased significantly from the minimum $\left(0.67\right.$ and $1.00 \%$ in $1^{\text {st }}$ year and $2^{\text {nd }}$ year, respectively) after 7 days of storage at ambient temperature to 4.89 and 5.45 percent in $1^{\text {st }}$ year and $2^{\text {nd }}$ year, respectively after 14 days of storage. The maximum rotting percentage $\left(7.33\right.$ and 7.11 in $1^{\text {st }}$ year and $2^{\text {nd }}$ year, respectively) was observed after 21 days of storage.

\section{Juice percentage}

The mean maximum juice percentage (45.93 and $45.87 \%$ in $1^{\text {st }}$ year and $2^{\text {nd }}$ year respectively) was noticed in hot water $\left(50^{\circ} \mathrm{C}\right)$ + sodium bicarbonate (2\%) and it was closely followed by hot water $\left(50^{\circ} \mathrm{C}\right)+$ sodium bicarbonate $(3 \%)$ where mean juice percentage was found to be 45.82 and 45.83 in $1^{\text {st }}$ yearand $2^{\text {nd }}$ year, respectively (Table 3 ). The mean minimum juice percentage (43.61and 43.49 in $1^{\text {st }}$ year and $2^{\text {nd }}$ year, respectively) was recorded in control. The 
remaining treatments had less reductive effect on juice percentage as compared with control. The perusals of data indicate that juice percentage of fruit decreased significantly with the advancement of storage period in all the treatment. The mean maximum juice percentage (46.99 and $46.92 \%$ in $1^{\text {st }}$ year and $2^{\text {nd }}$ year, respectively) was recorded after 7 days and minimum (44.02 and $44.12 \%$ in $1^{\text {st }}$ year and $2^{\text {nd }}$ year, respectively) after 21 days of ambient storage. The interaction between treatment and storage interval was found to be non-significant during both the years.

\section{Total soluble solids $\left({ }^{0} \mathrm{Brix}\right)$}

The mean total soluble solids after all storage interval was recorded maximum TSS $(9.57$ and $9.52^{\circ}$ Brix in $1^{\text {st }}$ year and $2^{\text {nd }}$ year, respectively) in hot water $\left(55^{\circ} \mathrm{C}\right)+$ sodium bicarbonate $(3 \%)$ followed by hot water $\left(55^{\circ} \mathrm{C}\right)+$ sodium bicarbonate $(2 \%)$ where TSS was found to be 9.53 and $9.48^{\circ}$ Brix in $1^{\text {st }}$ year and $2^{\text {nd }}$ year, respectively (Table 4$)$. The mean minimum TSS (9.26 and $9.23{ }^{\circ}$ Brix in $1^{\text {st }}$ year and $2^{\text {nd }}$ year, respectively) was recorded in hot water $\left(50^{\circ} \mathrm{C}\right)$ treatment. The perusal of data indicates that total soluble solids of fruit increased significantly with the advancement of storage period in all the treatments. The mean maximum TSS (9.51 and $9.45{ }^{\circ}$ Brix in $1^{\text {st }}$ year and $2^{\text {nd }}$ year, respectively) was recorded after 21 days and minimum TSS (9.27 and $9.23{ }^{\circ}$ Brix in $1^{\text {st }}$ year and $2^{\text {nd }}$ year, respectively) after 7 days of ambient storage. It was also observed that hot water $\left(55^{\circ} \mathrm{C}\right)$ and its combination with sodium bicarbonate $(2 \%$ or $3 \%$ ) exhibited increase in ${ }^{\circ}$ Brix as compared to other treatments as well as control. This might be due to the alteration in cell wall structure and breakdown of complex carbohydrate into simple sugars during storage.

Table.1 Effect of different treatments on physiological loss in weight (\%) of Kinnow fruits stored under ambient conditions

\begin{tabular}{|c|c|c|c|c|c|c|c|c|}
\hline \multirow[t]{3}{*}{ Treatments } & \multicolumn{8}{|c|}{ Storage intervals (days) } \\
\hline & \multicolumn{4}{|c|}{$1^{\text {st }}$ year } & \multicolumn{4}{|c|}{$2^{\text {nd }}$ year } \\
\hline & $\begin{array}{c}7 \\
\text { davs }\end{array}$ & $\begin{array}{c}14 \\
\text { davs }\end{array}$ & $\begin{array}{c}21 \\
\text { days }\end{array}$ & Mean & $\begin{array}{c}7 \\
\text { days }\end{array}$ & $\begin{array}{c}14 \\
\text { days }\end{array}$ & $\begin{array}{c}21 \\
\text { days }\end{array}$ & Mean \\
\hline Sodium bicarb. (2\%) & 2.34 & 4.41 & 6.81 & 4.52 & 2.33 & 4.36 & 6.79 & 4.49 \\
\hline Sodium bicarb. (3\%) & 2.38 & 4.45 & 6.87 & 4.57 & 2.37 & 4.39 & 6.83 & 4.53 \\
\hline Hot Water $\left(45^{\circ} \mathrm{C}\right)$ & 2.18 & 4.21 & 6.56 & 4.32 & 2.16 & 4.18 & 6.52 & 4.29 \\
\hline Hot Water $\left(50^{\circ} \mathrm{C}\right)$ & 2.15 & 4.18 & 6.52 & 4.28 & 2.13 & 4.16 & 6.48 & 4.26 \\
\hline Hot Water $\left(55^{\circ} \mathrm{C}\right)$ & 2.23 & 4.24 & 6.61 & 4.36 & 2.20 & 4.20 & 6.57 & 4.32 \\
\hline Hot Water $\left(45^{\circ} \mathrm{C}\right)+$ Sodium bicarb. $(2 \%)$ & 2.38 & 4.46 & 6.87 & 4.57 & 2.34 & 4.41 & 6.84 & 4.53 \\
\hline Hot Water $\left(50^{\circ} \mathrm{C}\right)+$ Sodium bcarb. $(2 \%)$ & 2.36 & 4.43 & 6.85 & 4.55 & 2.33 & 4.37 & 6.78 & 4.49 \\
\hline Hot Water $\left(55^{\circ} \mathrm{C}\right)+$ Sodium bicarb. $(2 \%)$ & 2.40 & 4.50 & 6.92 & 4.60 & 2.38 & 4.45 & 6.87 & 4.57 \\
\hline Hot Water $\left(45^{\circ} \mathrm{C}\right)+$ Sodium bi carb. $(3 \%)$ & 2.42 & 4.49 & 6.93 & 4.61 & 2.39 & 4.46 & 6.88 & 4.58 \\
\hline Hot Water $\left(50^{\circ} \mathrm{C}\right)+$ Sodium bicarb. $(3 \%)$ & 2.40 & 4.46 & 6.90 & 4.59 & 2.37 & 4.41 & 6.83 & 4.54 \\
\hline Hot Water $\left(55^{\circ} \mathrm{C}\right)+$ Sodium bicarb. $(3 \%)$ & 2.44 & 4.56 & 6.96 & 4.65 & 2.39 & 4.49 & 6.89 & 4.59 \\
\hline Control & 2.50 & 4.69 & 7.15 & 4.78 & 2.46 & 4.63 & 7.10 & 4.73 \\
\hline Mean & 2.35 & 4.42 & 6.83 & & 2.32 & 4.38 & 6.78 & \\
\hline $\mathrm{CD}(\mathrm{p}=\mathbf{0 . 0 5})$ & \multicolumn{2}{|c|}{$\begin{array}{l}\text { Storage interval } \\
\text { Treatment } \\
\text { Storage interval }\end{array}$} & \multicolumn{2}{|c|}{$\begin{array}{c}0.09 \\
0.18\end{array}$} & \multicolumn{2}{|c|}{$\begin{array}{l}\text { Storage interval } \\
\text { Treatment } \\
\text { Storage interval x }\end{array}$} & $\begin{array}{r}0.0 \\
0.13 \\
\text { reatment }\end{array}$ & \\
\hline Initial Value & & & & & & & & \\
\hline
\end{tabular}


Table.2 Effect of different treatments on rotting percentage of Kinnow fruits stored under ambient conditions

\begin{tabular}{|c|c|c|c|c|c|c|c|c|}
\hline \multirow[t]{2}{*}{ Treatments } & \multicolumn{4}{|c|}{$1^{\text {st }}$ year } & \multicolumn{4}{|c|}{$2^{\text {nd }}$ year } \\
\hline & $\begin{array}{c}7 \\
\text { days }\end{array}$ & $\begin{array}{c}14 \\
\text { days }\end{array}$ & $\begin{array}{c}21 \\
\text { days }\end{array}$ & Mean & $\begin{array}{c}7 \\
\text { days }\end{array}$ & $\begin{array}{c}14 \\
\text { days }\end{array}$ & $\begin{array}{c}21 \\
\text { days }\end{array}$ & Mean \\
\hline Sodium bicarb. (2\%) & 0.00 & 1.33 & 2.67 & 1.33 & 0.00 & 0.00 & 2.67 & 0.89 \\
\hline Sodium bicarb. (3\%) & 0.00 & 2.67 & 4.00 & 2.22 & 0.00 & 2.67 & 4.00 & 2.22 \\
\hline Hot Water $\left(45^{\circ} \mathrm{C}\right)$ & 0.00 & 4.00 & 6.67 & 3.56 & 0.00 & 4.00 & 5.33 & 3.11 \\
\hline Hot Water $\left(50^{\circ} \mathrm{C}\right)$ & 0.00 & 4.00 & 5.33 & 3.11 & 0.00 & 5.33 & 6.67 & 4.00 \\
\hline Hot Water $\left(55^{\circ} \mathbf{C}\right)$ & 4.00 & 10.67 & 12.00 & 8.89 & 5.33 & 10.67 & 13.33 & 9.78 \\
\hline Hot Water $\left(45^{\circ} \mathrm{C}\right)+$ Sodium bicarb. $(2 \%)$ & 0.00 & 2.67 & 6.67 & 3.11 & 0.00 & 2.67 & 5.33 & 2.67 \\
\hline Hot Water $\left(50^{\circ} \mathrm{C}\right)+$ Sodium bicarb. $(2 \%)$ & 0.00 & 2.67 & 5.33 & 2.67 & 0.00 & 5.33 & 6.67 & 4.00 \\
\hline Hot Water $\left(55^{\circ} \mathrm{C}\right)+$ Sodium bicarb. $(2 \%)$ & 1.33 & 6.67 & 9.33 & 5.78 & 2.67 & 6.67 & 8.00 & 5.78 \\
\hline Hot Water $\left(45^{\circ} \mathrm{C}\right)+$ Sodium bicarb. $(3 \%)$ & 0.00 & 4.00 & 8.00 & 4.00 & 0.00 & 5.33 & 6.67 & 4.00 \\
\hline Hot Water $\left(50^{\circ} \mathrm{C}\right)+$ Sodium bicarb. (3\%) & 0.00 & 5.33 & 8.00 & 4.44 & 0.00 & 6.67 & 8.00 & 4.89 \\
\hline Hot Water $\left(55^{\circ} \mathrm{C}\right)+$ Sodium bicarb. $(3 \%)$ & 2.67 & 8.00 & 10.67 & 7.11 & 4.00 & 9.33 & 10.67 & 8.00 \\
\hline Control & 0.00 & 6.67 & 9.33 & 5.33 & 0.00 & 6.67 & 8.00 & 4.89 \\
\hline Mean & 0.67 & 4.89 & 7.33 & & 1.00 & 5.45 & 7.11 & \\
\hline $\mathrm{CD}(\mathrm{p}=0.05)$ & $\begin{array}{l}\text { Storag } \\
\text { Treatm } \\
\text { Storag }\end{array}$ & $\begin{array}{l}\text { terval } \\
\text { terval } x\end{array}$ & eatment & $\begin{array}{c}0.92 \\
1.90 \\
\mathrm{NS}\end{array}$ & \multicolumn{4}{|c|}{$\begin{array}{l}\text { Treatment } \\
\text { Storage interval x Treatment NS }\end{array}$} \\
\hline Initial Value & \multicolumn{4}{|c|}{0.00} & \multicolumn{4}{|c|}{0.00} \\
\hline
\end{tabular}

Table.3 Effect of different treatments on juice percentage of Kinnow fruits stored under ambient conditions

\begin{tabular}{|c|c|c|c|c|c|c|c|c|}
\hline \multirow[t]{2}{*}{ Treatments } & \multicolumn{4}{|c|}{$1^{\text {st }}$ year } & \multicolumn{4}{|c|}{$2^{\text {nd }}$ year } \\
\hline & $\begin{array}{c}7 \\
\text { days }\end{array}$ & $\begin{array}{c}14 \\
\text { days }\end{array}$ & $\begin{array}{c}21 \\
\text { days }\end{array}$ & Mean & $\begin{array}{c}7 \\
\text { days }\end{array}$ & $\begin{array}{c}14 \\
\text { days }\end{array}$ & $\begin{array}{c}21 \\
\text { days }\end{array}$ & Mean \\
\hline Sodium bicarb. (2\%) & 46.82 & 45.34 & 44.21 & 45.46 & 46.79 & 45.26 & 44.14 & 45.40 \\
\hline Sodium bicarb. (3\%) & 46.66 & 44.32 & 44.18 & 45.05 & 46.60 & 44.23 & 44.10 & 44.98 \\
\hline Hot Water $\left(4^{\circ}{ }^{\circ} \mathrm{C}\right)$ & 47.24 & 45.62 & 44.37 & 45.74 & 47.15 & 45.58 & 44.28 & 45.67 \\
\hline Hot Water $\left(50^{\circ} \mathrm{C}\right)$ & 47.38 & 45.66 & 44.38 & 45.81 & 47.27 & 45.62 & 44.30 & 45.73 \\
\hline Hot Water $\left(55^{\circ} \mathbf{C}\right)$ & 46.82 & 45.65 & 44.40 & 45.62 & 46.73 & 45.60 & 44.36 & 45.56 \\
\hline Hot Water $\left(45^{\circ}\right.$ C) + Sodium bicarb. $(2 \%)$ & 47.34 & 45.00 & 44.53 & 45.62 & 47.27 & 45.62 & 44.39 & 45.76 \\
\hline Hot Water $\left(50^{\circ}\right.$ C) + Sodium bicarb. $(2 \%)$ & 47.41 & 45.82 & 44.56 & 45.93 & 47.34 & 45.76 & 44.51 & 45.87 \\
\hline Hot Water $\left(55^{\circ}\right.$ C) + Sodium bicarb. $(2 \%)$ & 47.11 & 45.80 & 44.49 & 45.80 & 47.00 & 45.74 & 44.44 & 45.73 \\
\hline Hot Water $\left(45^{\circ}\right.$ C) + Sodium bicarb. $(3 \%)$ & 47.21 & 45.63 & 42.42 & 45.09 & 47.13 & 45.59 & 44.36 & 45.69 \\
\hline Hot Water $\left(50^{\circ}\right.$ C) + Sodium bicarb. $(3 \%)$ & 47.32 & 45.67 & 44.47 & 45.82 & 47.28 & 45.72 & 44.49 & 45.83 \\
\hline Hot Water $\left(55^{\circ}\right.$ C) + Sodium bicarb. $(3 \%)$ & 46.92 & 45.60 & 44.43 & 45.65 & 46.87 & 45.53 & 44.37 & 45.59 \\
\hline Control & 45.62 & 43.36 & 41.85 & 43.61 & 45.57 & 43.18 & 41.73 & 43.49 \\
\hline Mean & 46.99 & 45.29 & 44.02 & & 46.92 & 45.29 & 44.12 & \\
\hline $\mathrm{CD}(\mathrm{p}=0.05)$ & $\begin{array}{l}\text { Storag } \\
\text { Treatn } \\
\text { Storag }\end{array}$ & $\begin{array}{l}\text { interva } \\
\text { ent } \\
\text { interva }\end{array}$ & Treatn & $\begin{array}{ll} & 0.82 \\
& \mathrm{NS} \\
\mathrm{n} & \mathrm{NS}\end{array}$ & $\begin{array}{l}\text { Storage } \\
\text { Treatm } \\
\text { Storage }\end{array}$ & $\begin{array}{l}\text { Aterval } \\
\text { t } \\
\text { aterval }\end{array}$ & Treatme & $\begin{array}{r}0.46 \\
0.96 \\
\text { NS }\end{array}$ \\
\hline Initial Value & \multicolumn{4}{|c|}{48.04} & \multicolumn{4}{|c|}{47.84} \\
\hline
\end{tabular}


Table.4 Effect of different treatments on TSS $\left({ }^{\circ}\right.$ Brix $)$ of Kinnow fruits stored under ambient conditions

\begin{tabular}{|c|c|c|c|c|c|c|c|c|}
\hline \multirow[t]{2}{*}{ Treatments } & \multicolumn{4}{|c|}{$1^{\text {st }}$ year } & \multicolumn{4}{|c|}{$2^{\text {nd }}$ year } \\
\hline & $\begin{array}{c}7 \\
\text { days }\end{array}$ & $\begin{array}{c}14 \\
\text { days }\end{array}$ & $\begin{array}{c}21 \\
\text { days }\end{array}$ & Mean & $\begin{array}{c}7 \\
\text { days }\end{array}$ & $\begin{array}{c}14 \\
\text { days }\end{array}$ & $\begin{array}{c}21 \\
\text { days }\end{array}$ & Mean \\
\hline Sodium bicarb. (2\%) & 9.27 & 9.32 & 9.47 & 9.35 & 9.23 & 9.25 & 9.34 & 9.27 \\
\hline Sodium bicarb. (3\%) & 9.28 & 9.39 & 9.52 & 9.40 & 9.24 & 9.27 & 9.37 & 9.29 \\
\hline Hot Water $\left(45^{\circ} \mathrm{C}\right)$ & 9.23 & 9.29 & 9.36 & 9.29 & 9.21 & 9.24 & 9.31 & 9.25 \\
\hline Hot Water $\left(\mathbf{5 0}^{\circ} \mathbf{C}\right)$ & 9.21 & 9.27 & 9.31 & 9.26 & 9.19 & 9.22 & 9.29 & 9.23 \\
\hline Hot Water $\left(55^{\circ} \mathrm{C}\right)$ & 9.31 & 9.52 & 9.68 & 9.50 & 9.26 & 9.34 & 9.62 & 9.41 \\
\hline Hot Water $\left(45^{\circ} \mathrm{C}\right)+$ Sodium bicarb. $(2 \%)$ & 9.24 & 9.30 & 9.39 & 9.31 & 9.21 & 9.25 & 9.33 & 9.26 \\
\hline Hot Water $\left(50^{\circ} \mathrm{C}\right)+$ Sodium bicarb. $(2 \%)$ & 9.22 & 9.28 & 9.35 & 9.28 & 9.2 & 9.23 & 9.30 & 9.24 \\
\hline Hot Water $\left(55^{\circ} \mathrm{C}\right)+$ Sodium bicarb. $(2 \%)$ & 9.33 & 9.54 & 9.71 & 9.53 & 9.28 & 9.47 & 9.68 & 9.48 \\
\hline Hot Water $\left(45^{\circ} \mathrm{C}\right)+$ Sodium bicarb. $(3 \%)$ & 9.26 & 9.33 & 9.43 & 9.34 & 9.22 & 9.30 & 9.40 & 9.31 \\
\hline Hot Water $\left(50^{\circ} \mathrm{C}\right)+$ Sodium bicarb. $(3 \%)$ & 9.25 & 9.31 & 9.40 & 9.32 & 9.21 & 9.27 & 9.38 & 9.29 \\
\hline Hot Water $\left(55^{\circ} \mathrm{C}\right)+$ Sodium bicarb. $(3 \%)$ & 9.36 & 9.6 & 9.76 & 9.57 & 9.30 & 9.52 & 9.74 & 9.52 \\
\hline Control & 9.30 & 9.50 & 9.67 & 9.49 & 9.25 & 9.34 & 9.6 & 9.40 \\
\hline Mean & 9.27 & 9.39 & 9.50 & & 9.23 & 9.31 & 9.45 & \\
\hline $\mathrm{CD}(\mathrm{p}=0.05)$ & \multicolumn{3}{|c|}{$\begin{array}{l}\text { Storage interval } \\
\text { Treatment } \\
\text { StorageintervalxTre }\end{array}$} & $\begin{array}{l}0.03 \\
0.06 \\
0.10\end{array}$ & \multicolumn{4}{|c|}{$\begin{array}{lr}\text { Storage interval } & 0.04 \\
\text { Treatment } & 0.09 \\
\text { Storage interval x Treatment NS }\end{array}$} \\
\hline Initial Value & \multicolumn{4}{|c|}{9.23} & \multicolumn{4}{|c|}{9.20} \\
\hline
\end{tabular}

Table.5 Effect of different treatments on acidity (\%) of Kinnow fruits stored under ambient conditions

\begin{tabular}{|c|c|c|c|c|c|c|c|c|}
\hline \multirow[t]{2}{*}{ Treatments } & \multicolumn{4}{|c|}{$1^{\text {st }}$ year } & \multicolumn{4}{|c|}{$2^{\text {nd }}$ year } \\
\hline & $\begin{array}{c}7 \\
\text { days }\end{array}$ & $\begin{array}{c}14 \\
\text { days }\end{array}$ & $\begin{array}{c}21 \\
\text { days }\end{array}$ & Mean & $\begin{array}{c}7 \\
\text { days }\end{array}$ & $\begin{array}{c}14 \\
\text { days }\end{array}$ & $\begin{array}{c}21 \\
\text { days }\end{array}$ & Mean \\
\hline Sodium bicarb. (2\%) & 0.63 & 0.61 & 0.59 & 0.61 & 0.65 & 0.63 & 0.62 & 0.63 \\
\hline Sodium bicarb. (3\%) & 0.62 & 0.60 & 0.58 & 0.60 & 0.64 & 0.61 & 0.61 & 0.62 \\
\hline Hot Water $\left(45^{\circ} \mathrm{C}\right)$ & 0.64 & 0.62 & 0.61 & 0.62 & 0.65 & 0.64 & 0.62 & 0.64 \\
\hline Hot Water $\left(50^{\circ} \mathrm{C}\right)$ & 0.65 & 0.63 & 0.62 & 0.63 & 0.67 & 0.65 & 0.62 & 0.65 \\
\hline Hot Water $\left(55^{\circ} \mathbf{C}\right)$ & 0.63 & 0.62 & 0.64 & 0.63 & 0.63 & 0.62 & 0.65 & 0.63 \\
\hline Hot Water $\left(45^{\circ} \mathrm{C}\right)+$ Sodium bicarb. $(2 \%)$ & 0.64 & 0.62 & 0.61 & 0.62 & 0.65 & 0.63 & 0.61 & 0.63 \\
\hline Hot Water $\left(50^{\circ} \mathrm{C}\right)+$ Sodium bicarb. $(2 \%)$ & 0.66 & 0.64 & 0.62 & 0.64 & 0.68 & 0.66 & 0.63 & 0.66 \\
\hline Hot Water $\left(55^{\circ} \mathrm{C}\right)+$ Sodium bicarb. $(2 \%)$ & 0.62 & 0.61 & 0.63 & 0.62 & 0.64 & 0.63 & 0.64 & 0.64 \\
\hline Hot Water $\left(45^{\circ} \mathrm{C}\right)+$ Sodium bicarb. $(3 \%)$ & 0.64 & 0.62 & 0.60 & 0.62 & 0.65 & 0.64 & 0.63 & 0.64 \\
\hline Hot Water $\left(50^{\circ} \mathrm{C}\right)+$ Sodium bicarb. $(3 \%)$ & 0.64 & 0.63 & 0.61 & 0.63 & 0.66 & 0.65 & 0.63 & 0.65 \\
\hline Hot Water $\left(55^{\circ} \mathrm{C}\right)+$ Sodium bicarb. $(3 \%)$ & 0.61 & 0.59 & 0.63 & 0.61 & 0.63 & 0.62 & 0.64 & 0.63 \\
\hline Control & 0.60 & 0.58 & 0.57 & 0.58 & 0.62 & 0.60 & 0.58 & 0.60 \\
\hline Mean & $\mathbf{0 . 6 3}$ & 0.61 & 0.61 & & 0.65 & 0.63 & 0.62 & \\
\hline $\mathrm{CD}(\mathrm{p}=\mathbf{0 . 0 5})$ & \multicolumn{2}{|c|}{$\begin{array}{l}\text { Storage interval } \\
\text { Treatment }\end{array}$} & x Treatn & $\begin{array}{l}017 \\
\text { NS } \\
\text { at - NS }\end{array}$ & \multicolumn{2}{|c|}{$\begin{array}{l}\text { Storage interval } \\
\text { Treatment }\end{array}$} & Treatment & $\begin{array}{c}0.010 \\
0.021 \\
\mathrm{NS}\end{array}$ \\
\hline Initial Value & \multicolumn{4}{|c|}{0.67} & \multicolumn{4}{|c|}{0.69} \\
\hline
\end{tabular}




\section{Acidity (\%)}

The mean acidity per cent after all the storage intervals was recorded maximum (0.64 and $0.66 \%$ in $1^{\text {st }}$ year and $2^{\text {nd }}$ year) respectively) in hot water $\left(50^{\circ} \mathrm{C}\right)+$ sodium bicarbonate $(2 \%)$ and mean minimum $(0.58$ and $0.60 \%$ in $1^{\text {st }}$ year and $2^{\text {nd }}$ year, respectively) acidity was recorded in control (Table 5). The acidity of fruits decreased significantly with the advancement of storage period in all the treatments except in hot water $\left(55^{\circ} \mathrm{C}\right)$ and its combination with sodium bicarbonate $(2 \%$ or $3 \%)$ where acidity was found to be increased after 14 days of storage might be due to the fermentation of sugars resulting in production of acids. Fruits those dipped in hot water at $55^{\circ} \mathrm{C}$ and its combination with sodium bicarbonate $(2 \%$ or $3 \%)$ however, developed off-flavor, which was probably due to the increased ethanol level. The mean maximum acidity $\left(0.63\right.$ and $0.65 \%$ in $1^{\text {st }}$ year and $2^{\text {nd }}$ year, respectively) was recorded after 7 days and minimum acidity $\left(0.61\right.$ and $0.62 \%$ in $1^{\text {st }}$ year and $2^{\text {nd }}$ year respectively) after 21 days of ambient storage.

The combined influence of treatments and duration of ambient storage had a significant reflection on physiological loss in weight. Our results are in agreement with those of Schirra et al., (2008) who reported that the rate of weight loss of Valencia oranges was significantly increased by sodium bicarbonate treatment of stored Valencia oranges after 20 days at $17^{\circ} \mathrm{C}$ and $90 \%$ relative humidity after 1 min dip in an aqueous mixture of sodium bicarbonate at $0.5,1$ or 2 per cent (weight /volume) at 20 or $40^{\circ} \mathrm{C}$. Similarly, fruits dipped in hot water at $50^{\circ} \mathrm{C}$ for $5 \mathrm{~min}$ had a shelf life of up to 14 days with a minimum weight loss of $13 \%$ even on the $15^{\text {th }}$ day of storage (Vijayalakshmi et al., 2004). Similarly, decrease in physiological loss of weight in Clementine with hot water dip and sodium bicarbonate was also reported by
Larrigaudierre et al., (2002). The mode of action of hot water dip in reducing percentage of loss in fruit weight could be due to the melting of fruit epicuticular waxes which covers and seal the stomata and cracks on fruit surface. The results show that there was a continuous increase in rotting percentage with increase in storage duration. It might be due to the weakening of the defense system against fungal attack. The combined influence of treatments and duration of ambient storage had a significant reflection on physiological loss in weight. Our results are in agreement with the findings of Ratnayake et al., (2009) who observed that sodium bicarbonate treatment controlled the decay by $100 \%$ in wood apple. Ben-Yehoshua et al., (2000) also reported that the effective temperature range for 2 minute grapefruit dip treatments was between 51 and $54^{\circ} \mathrm{C}$, as temperatures above $54^{\circ} \mathrm{C}$ caused brown discoloration of the peel and temperatures below $51^{\circ} \mathrm{C}$ were not effective in reducing decay.

The results revealed that all the treatments resulted in higher juice content than control. It was especially due to increase permeability in cell wall with heat treatment. The significant decrease in juice percentage with prolongation of storage may be due to continous dehydration of peel and juice. Similar, results were reported previously by Larrygaudiere et al., (2002) in Clementines. The results revealed that hot water up to $50^{\circ} \mathrm{C}$ exhibited the decrease in TSS. Initially may be due to more utilization of sugars than conversion of complex carbohydrates into simple sugars by the fruit to fulfill energy demand. Heat treatment seems to delay the development of TSS, since heat treatments slow down the ripening process. A gradual decrease in TSS was observed in all samples during storage, although a typical phenomenon would be a general increase in the solute concentration due to the water loss. This result may have been related to the 
persistent consumption of sugars and organic acids for plant tissue metabolism, rather than the solute concentration effects during longterm storage. The results obtained in the present studies are in agreement with the findings of Khan et al., (2007) who studied on ambient storage of sweet orange cv. Blood Red after subjecting to heat treatments for 0 , 5,10 and 15 minutes in water at $50^{\circ} \mathrm{C}$ revealed that total soluble solids content increased with increasing storage duration up to 45 days, but decreased when storage period was prolonged up to 60 days and heat treatments delayed TSS increase.

The difference between storage intervals was also found to be significant. The interaction between treatment and storage interval was found to be non-significant during both the years. It was observed that percent titratable acidity had decreasing trend during 21 days of storage period that might be due to the degradation of citric acid which could be attributed to increased activity of citric acid glyoxylase during ripening or reduction in acidity may be due to its conversion into sugars and their further utilization in metabolic process of the fruit. The results are in agreement with the findings of Obaid et al., (2010) who reported a significant decrease in acidity (0.90-0.68 \%) in hot water dipped Blood Red orange fruits at different temperatures $\left(45,50,55\right.$ and $\left.60^{\circ} \mathrm{C}\right)$. In contrast, SeokIn et al., (2007) mentioned hot water treatment also had no adverse effects on titratable acidity in Satsuma mandarins (Citrus unshiu Marc cv. Gungchun) of an early harvesting cultivar after treated by hot water dipping at $52^{\circ} \mathrm{C}$ for $2 \mathrm{~min}, 55^{\circ} \mathrm{C}$ for 1 min, and $60^{\circ} \mathrm{C}$ for $20 \mathrm{~s}$, and then stored at $5^{\circ} \mathrm{C}$ for 3 weeks and subsequently at $18^{\circ} \mathrm{C}$ for 1 week.

It was concluded that hot water $\left(50^{\circ} \mathrm{C}\right)$ and hot water $(50 \mathrm{C})+$ sodium bicarbonate $(2 \%)$ proved to be better treatment in improving the overall quality and extending the shelf life of Kinnow fruits under ambient storage conditions.

\section{References}

AOAC 1990. Official and Tentative Methods of Analytical Chemists, Washington DC, USA $14^{\text {th }}$ edition.

Ben-Yehoshua, B. Peretz, S. J., Rodov, V., Nafussi, B., Yekutieli, O., Wiseblum, A., Regev, R., Herregods, M., Nicolai, M., Jager, A. and Roy, S. K. 2000. Postharvest application of hot water treatment in citrus fruits: the road from the laboratory to the packing-house. Acta Hort. 518: 19-28.

Couey, H.M. 1989. Heat treatment for control of postharvest diseases and insect pests of fruits. Hort Sci. 24 (2): 198-202.

Fallik, E. 2004. Prestorage hot water treatments (immersion, rinsing and brushing). Posthar Bio Tech. 32:125134.

Fallik, E., Tuvia-Alkalai, S., Feng, X., Lurie, S., 2001. Ripening characterisation and decay development of stored apples after a short pre-storage hot water rinsing and brushing. Innovative Food Sci Emer Tech. 2: 127-132.

Gautam, B., Sarkar, S. K., and Reddy, Y. N. 2003. Effect of postharvest treatments on shelf-life and quality of Banganapalli mango. Ind J Hort. 60:135-139.

Khan, G. A,, Rab, A., Sajid, M. and Salimullah 2007. Effect of heat and cold treatments on post harvest quality of sweet orange cv. blood red. Sarhad J Agri 23: 39-44.

Larrigaudiere, C., Pons, J., Torres, R. and Usall, J. 2002. Storage performance of clementines treated with hot water sodium carbonate and sodium bicarbonate dips. J Hort Sci Biotech. 77: 314-319.

Maleki, M. and Sarkissian, L. 1967. Effect of 
canning and storage on the chemical composition and organoleptic quality of juices of different varieties oranges grown in Lebanan. J Food Sci Agri.18: 501-504.

Obaid, J., Khalil, S. A,, Khattak, A. B,, Khan, M. and Ayub, M. 2010. Effect of hot water dipping on the postharvest life of blood red oranges. Advances in Food Sci. 32: 82-87.

Palou, L., Usall, J., Munoz, J. A., Smilanick, J. and Land Vinas, I. 2002. Hot water sodium carbonate and sodium bicarbonate for the control of postharvest green and blue moulds of Clementine mandarins. Posthar BioTech 24: 93-96.

Panse, V. G. and Sukhatame, P. V. 1976. Statistical method for agricultural workers ICAR, New Delhi.

Purvis, A. C. 1985. Relationship between chilling injury of grape fruit and moisture loss during storage. Amelioration by polyethylene shrink film. J Amer Soc Hort Sci. 110: 385388.

Ratnayake, R. M. R. N. K., Sumithra, H. J, Fernando, M. D. and Palipane, K. B.
2009. Effect of GRAS compounds on Aspergillus rot of woodapple (Feronia limonia). Phyto Parasitica 37: 431-436.

Schirra, M., Aquino, D. S., Palma, A., Angioni, A. and Cabras, P. 2008. Factors affecting the synergy of thiabendazole sodium bicarbonate and heat to control postharvest green mold of citrus fruit. J Agri Food Chem. 56: 10793-10798.

SeokIn, H., Hyun, H. L. and Dong, M. K. 2007. Effects of hot water treatment on the storage stability of satsuma mandarin as a postharvest decay control. Post-harvest Bio Tech 43(2): 271-279.

Venditti, M. G., Molinu, A., Dore, M. and Hallewin, D.G. 2005. Sodium carbonate treatment induces scoparone accumulation, structural changes, and alkalinisation in the albedo of wounded citrus fruit. J Agri Food Chem 53: 3510-3518.

Vijayalakshmi, D., Bangarusamy, U. and Vijayakumari, R. M. 2004. Post-harvest treatments to extend the shelf life of sapota fruit cultivars Co 1 and Co 2 . Crop Research 27(2/3): 219-226.

\section{How to cite this article:}

Rachna Singla, H.S. Rattanpal and Gurteg Singh. 2018. Storage Performance of Hot Water Treated Kinnow Fruits under Ambient Conditions. Int.J.Curr.Microbiol.App.Sci. 7(06): 37753782. doi: https://doi.org/10.20546/ijcmas.2018.706.442 